\title{
PERSPEKTIF SOSIOLOGIS KONSEP KEBIJAKAN GERAKAN PEMBANGUNAN MASYARAKAT ISLAMI (GERBANGSALAM) DI KABUPATEN PAMEKASAN \\ (Jawaban Terhadap Wacana Pemisahan Agama dengan Politik)
}

\author{
Hendri Masduki \\ Universitas Madura (UNIRA) Pamekasan \\ Email: hendri.pgri@gmail.com
}

\begin{abstract}
Abstrak:
Para Islamis dewasa ini tengah mencari alternatif-solutif untuk menyelesaikan masalah domestik pemerintahannya, mereka tidak melihat ideologi barat sebagai alternatif penyelesaian masalah domestiknya, namun mereka berpaling dan menjadikan Islam sebagai pegangan dan solusi alternatif untuk mengatasi masalah domestik daerahnya, dan bahkan mereka mendengungkan sebuah slogan "Islam is the solution" dan bahkan mereka mengartikulasi dan memberikan interpretasi suatu kebebasan dalam frame reference Syari'at Islam. Tren inilah yang menjadi proritas utama para elit lokal di daerah untuk mengelola, dan menata pemerintahan di daerahnya. Penataan dan pengelolaan pemerin-tahan secara otonom di tingkat lokal (local state) merupakan dampak sosial gerakan reformasi total pada tahun 1998 yang disusul bergulirnya spirit otonomi daerah, yang menghendaki perubahan paradigma pemerintahan dari sentralisasi birokrasi menuju desentrasasi demokrasi, sehingga pemerintahan di daerah dituntut mempunyai kemampuan dalam mengelola pemerintahan dan mengatasi masalah-masalah domestiknya sesuai dengan potensi dan khasanah kearifan lokal yang dimiliki di daerahnya. Realitas inilah yang mendorong pemerintahan di daerah-daerah (local state) untuk membuat regulasi kebijakan, baik dalam bentuk peraturan daerah (Perda), Keputusan-keputusan, dan bahkan yang masih berupa rencana strategis.
\end{abstract}

Kata Kunci: Perspektif sosiologis, Konsep kebijakan Gerbangsalam, Kabupaten Pamekasan.

Abstract:

Todays, All Islamic are searching an alternatif-solution to finish the problem of domestic government, they don't use the west 
Perspektif sosiologis konsep kebijakan

Gerakan pembangunan masyarakat islami (gerbangsalam)

Di kabupaten pamekasan

ideology as the guidance or an alterntif of problem solving, but they deny and take Islam as the quidence and an alternative solution to overcome the problem, and even they show the slogan "Islam is the solution" and even they submit and give an interpretation of freedom in frame reference of Syari'at Islam. This Tren become main proritas to all local elite in local state to manage and arrange the governance. The arragement and management of the governance otonomously in local state is representing the social impact of total reformation movement in 1998 which is continued by occuring spirit of area autonomy, wanting changging of the government paradigm from sentralisasi of bureaucracy to desentrasasi of democracy, so that the governance in local state are hoped to own ability in managing governance and overcoming the domestic problem based on the potention and local properties or asset they have. This reality make the governance in the local state take the regulation of rules, it can be an autonomous rule (Perda), The decisions, and even the rule in the form of strategic plan

Keywords: Sociology Perspective, the Concept of the Rule of Movement of Islamic Socity Development (GERBANGSALAM), Pamekasan Regency

\section{Prolog}

Gerakan pembangunan masyarakat Islami (Gerbangsalam) merupakan suatu kebijakan sebagai dampak dari reformasi total pada tahun 1998 dan disusul dengan bergulirnya otonomi daerah pada tahun 1999 yang mendorong pemerintah di daerah untuk mengatur pemerintahannya sesuai dengan aspirasi dan kehendak masyarakatnya. Undang-undang No. 22 tahun 1999 tentang pokok-pokok pemerintahan daerah, secara manifest memuat semangat otonomi daerah yang secara paradigmatik merupakan titik awal dalam perubahan penataan pemerintahan antara penguasa dengan rakyat, dan juga antara pemerintah pusat dengan pemerintah daerah, yang secara subtantif memberikan peluang yang seluas-luasnya terhadap pemerintahan di daerah untuk mengatur pemerintahannya sendiri. Paradigma baru tersebut ditandai dengan peralihan sistem pemerintahan dari sentralisasi birokrasi menuju desentralisasi demokrasi yang merimplikasi terhadap perubahan paradigma pemerintahan di-tingkat lokal (local state). Perubahan ini tidak hanya berimplikasi terhadap perubahan dalam aspek politik dan kekuasaan, namun lebih dari itu, juga berimplikasi terhadap perubahan dalam segala 
Perspektif sosiologis konsep kebijakan

Gerakan pembangunan masyarakat islami (gerbangsalam)

Di kabupaten pamekasan

aspek kehidupan termasuk perubahan sosial budaya dalam kehidupan berbangsa dan bernegara.

Dalam perkembangannya, spirit otonomi daerah (Otoda) juga tercermin dalam Undang-undang Nomor 32 Tahun 2004 tentang Pemerintahan Daerah, yang secara tegas menyatakan bahwa pemerintahan daerah mengatur dan mengurus sendiri urusan pemerintahan menurut asas otonomi daerah dan tugas pembantuan, dan kemudian menjadi landasan perubahan paradigma dalam sistem pemerintahan yang akhir-akhir ini telah menjadi trent, prioritas, dan bahkan proyek para elite di tingkat lokal (local state) utamanya yang menginginkan konsep Syari'at Islam menjadi landasan ideologis, landasan berperilaku, dan bahkan landasan dalam penataan pemerintahan di daerah, yang pada perkembangannya memicu lahirnya produk hukum yuridis formal dalam dinamika politik pemerintahan di daerah (local state) untuk menformalisasikan konsep syari'at Islam dalam bentuk kebijakan, baik berupa peraturan daerah (Perda), Keputusan Bupati/Wali Kota, dan bahkan yang hanya berupa surat edaran, yang secara implisit bermuatan khasanah kearifan lokal daerahnya masing-masing. ${ }^{1}$

Produk hukum berupa kebijakan yang telah diformalisasikan tersebut dicurigai sengaja diambil dari ketentuan-ketentuan legal Syari'at Islam baik tekstual maupun subtansial yang diyakini menjadi alternatif solutif dalam mengatasi masalah bangsa ini utamanya dalam dinamika pemerintah lokal (local state), ${ }^{2}$ sebagaimana pendapat "Samuel Huntington" yang menyatakan bahwa:

"Para Islamis dewasa ini tengah mencari alternatif-solutif untuk menyelesaikan masalah domestiknya, mereka tidak melihat ideologi barat sebagai alterntif penyelesaian masalah domestiknya, namun mereka berpaling dan menjadikan Islam sebagai pegangan dan alternatif-solutif untuk mengatasi masalah domestik daerahnya, dan bahkan mereka mendengungkan sebuah slogan "Islam is the solution" dan bahkan mereka mengartikulasi dan memberikan interpretasi suatu kebebasan dalam frame reference Syari'at Islam". ${ }^{3}$

\footnotetext{
${ }^{1}$ Muhammad Alim, Perda-Perda Bernuansa Islam dan Hubungannya Dengan Konstitusi, (Jakarta: Mahkamah Konstitusi Republik Indonesia, Jurnal Hukum, Vol 17 Januari 2010:119142). hlm 2.

${ }^{2}$ Rumadi, Perda syari'ah Islam: Jalan lain menuju Negara Islam?" (Tahwirul Afkar: Jurnal Refleksi Pemikiran Keagamaan dan Kebudayaan Islam; Perda Syari'at Islam Menuai Makna, Edisi No. 20 Tahun 2006). hlm 3.

${ }^{3}$ Ridwan Al-Markassary, Matinya Kebesan Sipil di-tengah Kuasa Perda Syari'ah Islam di Indonesia, http://www.csrc.or.id.
} 
Perspektif sosiologis konsep kebijakan

Gerakan pembangunan masyarakat islami (gerbangsalam)

Di kabupaten pamekasan

Keyakinan terhadap Islam sebagai alternatif solutif dalam upaya untuk mengatasi masalah-masalah sosial bukanlah tanpa alasan, hal ini dipicu karena Islam bukan hanya sekadar sebuah agama, namun lebih dari itu, Islam juga sebagai sebuah sistem kehidupan, yang diyakini tidak saja mampu memberi petunjuk bagi manusia kepada jalan yang menuju keselamatan dan kebahagiaan hidup di akhirat, akan tetapi Islam juga agama yang memberi petunjuk menuju keselamatan dan kebahagiaan hidup di dunia. Islam bukan hanya sistem kepercayaan, namun juga sistem kehidupan yang universal. Islam bukan hanya berurusan dengan persoalan ritual keagamaan, akan tetapi juga berurusan dengan persoalan sosial kemanusiaan, sosial ekonomi, dan bahkan ketatanegaraan. Kondisi yang demikian itulah dapat disinyalir bahwa keberadaan Islam tidak hanya mengajarkan kepada manusia bagaimana harus mempersiapkan kehidupan di akhirat semata, namun lebih dari itu, Islam juga mengajarkan bagaimana harus mempersiapkan kehidupan di dunia sebagai bekal serta modal utama untuk kehidupan di akhirat kelak. Firman Allah SWT dalam al-Qur'an:

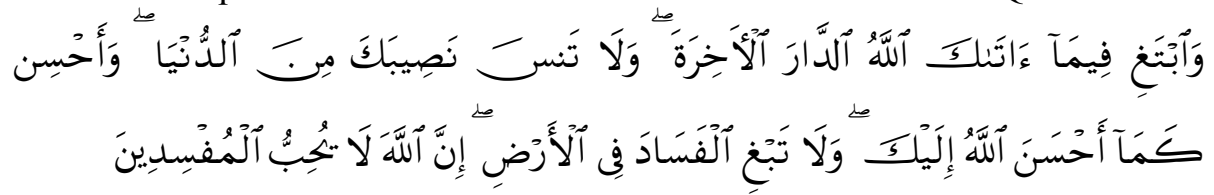

"Dan carilah pada apa yang telah dianugerahkan Allah SWT kepadamu (kebahagiaan) negeri akhirat, dan janganlah kamu melupakan kebahagiaanmu dari (kenikmatan) duniawi sebagaimana Allah SWT telah berbuat baik kepadamu, dan janganlah kamu berbuat kerusakan di muka bumi. Sesungguhnya Allah tidak menyukai orang-orang yang berbuat kerusakan”. (QS. Al-Qașaș: 77). ${ }^{4}$

Gerakan pembangunan masyarakat Islami (Gerbangsalam) sebagai suatu konsep dan kebijakan di Kabupaten Pamekasan meliputi tiga bidang garapan, yaitu bidang Aqidah, Syariat dan Akhlaq. Dari ketiga aspek tersebut diharapkan dapat menghasilkan pribadi muslim yang kāmil dan shāmil, yang dalam hal ini memuat beberapa misi yaitu: Pertama, membangun keluarga sakinah; Kedua, membangun nuansa pendidikan yang Islami; dan Ketiga, membangun aparatur pemerintah yang Islami. Dari ketiga misi tersebut sehingga terwujud tatanan masyarakat yang Islami serta kesejahteraan dan ketentraman masyarakat. ${ }^{5}$

\footnotetext{
${ }^{4}$ Mahmud Yunus, Terjemah Al-Qur'an Al Karim, (Bandung: Alma'arif, 1967) hlm 572.

${ }^{5}$ Tim Lembaga pengkajian dan penerapan syari'at Islam (LP2 SI) Kabupaten Pamekasan, Buku Saku Gerbang Salam: Mengenal Gerbang Salam, (Pamekasan: LP2SI Pamekasan, 2011). hlm 3.
} 
Perspektif sosiologis konsep kebijakan

Gerakan pembangunan masyarakat islami (gerbangsalam)

Di kabupaten pamekasan

\section{Perspektif Sosiologis Konsep Kebijakan Gerakan Pembangunan Masyarakat Islami (Gerbangsalam) Di Kabupaten Pamekasan}

Istilah kebijakan dalam bahasa Inggris policy yang dibedakan dari kata wisdom yang berarti kebijaksanaan atau kearifan. Kebijakan merupakan pernyataan umum perilaku daripada organisasi. Kebijakan merupakan garis pedoman untuk pengambilan keputusan. ${ }^{6}$ Kebijakan merupakan sesuatu yang bermanfaat dan juga merupakan penyederhanaan sistem yang dapat membantu dan mengurangi masalah-masalah dan serangkaian tindakan untuk memecahkan masalah tertentu, oleh sebab itu suatu kebijakan dianggap sangat penting. Kebijakan merupakan serangkaian tujuan dan sasaran program-program pemerintah. Kartasasmita menyatakan bahwa kebijakan merupakan upaya untuk memahami dan mengartikan. Pertama, apa yang dilakukan atau tidak dilakukan oleh pemerintah mengenai suatu masalah; Kedua, apa yang menyebabkan atau yang mempengaruhinya; dan Ketiga, apa pengaruh atau dampak dari kebijakan tersebut. ${ }^{7}$ Kebijakan publik adalah semacam jawaban terhadap suatu masalah karena sebagai upaya untuk memecahkan, mengurangi, dan mencegah suatu keburukan dan sebaliknya menjadi penganjur, inovasi, dan pemuka terjadinya kebaikan dengan cara terbaik dan tindakan yang terarah. ${ }^{8}$

Kebijakan tidak sekedar suatu aturan tetapi lebih dari itu kebijakan perlu dipahami secara utuh dan benar sehingga apa yang diharapkan dari ending suatu kebijakan dapat tercapai. Ketika suatu issue yang menyangkut kepentingan bersama dipandang perlu untuk diatur maka formulasi issue tersebut menjadi kebijakan publik yang harus dilakukan dan disusun serta disepakati oleh para pejabat yang berwewenang. Begitu juga ketika kebijakan tersebut ditetapkan menjadi suatu kebijakan publik, apakah menjadi undang-undang, Peraturan, atau keputusan, maka kebijakan tersebut berubah menjadi hukum yang harus ditaati. Itulah sebabnya, Anderson berpendapat bahwa kebijakan adalah suatu tindakan yang mempunyai tujuan yang dilakukan seseorang pelaku atau sejumlah pelaku untuk memecahkan suatu masalah. ${ }^{9}$

\footnotetext{
${ }^{6}$ Sihombing Sirait, Manjemen, (Jakarta: Bumi aksara, 1991). hlm 115.

${ }^{7}$ Joko Widodo, Analisis Kebijakan Publik, (Malang, Bayumedia Publishing, 2007). hlm 1213.

${ }^{8}$ Inu Kencana Syafiie, Ilmu Administrasi Publik, (Jakarta: Rineka Cipta, 2007). hlm 104.

9 Arifin Tahir, Analisis Omplementasi Kebijakan Empat Pilar Pengembangan Universitas Negeri Gorontalo, (Gorontalo: Universitas Negeri Gorontalo, 2012). hlm. 1.
} 
Perspektif sosiologis konsep kebijakan

Gerakan pembangunan masyarakat islami (gerbangsalam)

Di kabupaten pamekasan

Bergulirnya otonomi daerah yang ditandai dengan peralihan sistem pemerintahan dari sentralisasi birokrasi menuju desentralisasi demokrasi ${ }^{10}$ yang merimplikasi terhadap lahir dan tumbuh kembangnya kebijakan lokal (local state) di Kabupaten Pamekasan, yang kemudian dikenal dengan istilah GERBANGSALAM (Gerakan pembangunan masyarakat Islami) sebagai model dan strategi dakwah Islamiyah di Kabupaten Pamekasan, yang diyakini bisa menjadi pegangan dan solusi alternatif untuk bisa mengatasi masalah-masalah domestik pemerintahan demi terwujudnya masyarakat Pamekasan yang sejahtera yang dijiwai dengan nilai-nilai Islam yang diridhai Allah SWT.

Konsep kebijakan Gerakan pembangunan masyarakat Islami (Gerbangsalam) adalah produk kebijakan berdasarkan Surat Keputusan Bupati Pamekasan Nomor 188/126/441.012/2002, Tanggal 30 April 2002, Surat keputusan Bupati Pamekasan nomor 188/340/44.131/2009, Tanggal, 19 Oktober 2009, tentang penetapan Gerakan pembangunan masyarakat Islami (Gerbangsalam) sebagai model dan strategi dakwah di Kabupaten Pamekasan. ${ }^{11}$ Secara subtantif Gerakan pembangunan masyarakat Islami (Gerbangsalam) adalah upaya bersama yang dilakukan secara sistematis dan terus menerus dalam rangka mentransformasi nilai-nilai ajaran Islam dalam kehidupan sehari-hari. Kebijakan ini dilatarbelakangi dengan beberapa faktor Pertama, Kewajiban untuk menjalankan syari'at Islam secara kaffah; Kedua, Momentum reformasi yang membuka peluang untuk memasukkan nilai-nilai ajaran Islam dalam rumusan kebijakan di era otonomi daerah; Ketiga, Lahirnya peraturan daerah tentang larangan minuman beralkohol; Keempat, Adanya seminar-seminar dan bahsul masail tentang pentingnya penerapan hukum, dan atau syari'at Islam sebagai forum yang menghimpun keinginan sebagian besar masyarakat Kabupaten Pamekasan sebagai satu dari empat Kabupaten di wilayah areal Pulau Garam ${ }^{12}$ yang berpenduduk mayoritas muslim.

\footnotetext{
${ }^{10}$ Undang-undang Nomor 32 Tahun 2004 tentang Pemerintahan Daerah.

11 Tim Lembaga Pengkajian dan Penerapan Syari'at Islam (LP2SI) Kabupaten Pamekasan, "Buku Saku Gerbang Salam: Mengenal Gerbang Salam, Ibid. hlm 2.

12 Pulau "Garam" adalah sebutan lain dari "Pulau Madura" yang sangat populer selama ini. Madura yang sering disebut dengan Pulau "Garam" secara distrik pemerint ahan dan penataan administrasi ketatanegaraan mulai dari sejak zaman kolonial Belanda sebagai wilayah Kresidenan (Residen Madura) yang meliputi empat Kabupaten yaitu: Bangkalan, Sampang, Pamekasan, dan Sumenep. Istilah "Pulau Garam" untuk "Madura" karena "Garam" adalah komoditas unggulan masyarakat Madura dalam sisi ekonomi, selain komoditas tataniaga tembakau. Namun lebih dari itu, "Garam" juga menjadi icon identitas, dan sosial budaya masyarakat Madura selama ini. "Garam" sebagai komoditas ekonomi, identitas, dan bahkan sosial budaya telah menghantarkan "Madura" dikenal ditingkat Nasional, dan bahkan
} 
Perspektif sosiologis konsep kebijakan

Gerakan pembangunan masyarakat islami (gerbangsalam)

Di kabupaten pamekasan

Konsep kebijakan Gerakan pembangunan masyarakat Islami (Gerbangsalam) bermula dari adanya wacana miring bahwa, masyarakat Pamekasan telah kehilangan jati dirinya. Banyak orang muslim melakukan perbuatan yang dilarang syari'at. Seperti semakin meningkatnya prostitusi, pemerkosaan, dan banyak wanita yang tidak sungkan mempertontonkan auratnya. Semua itu menurut para ulama disebabkan oleh hilangya jati diri mereka sebagai orang muslim, dan tidak menyadari bahwa perbuatan yang mereka lakukan sebenarnya telah melanggar syari'at. Tujuan dari Gerbang Salam untuk mewujudkan motto kabupaten Pamekasan yaitu "Mekkas Jatnah Paksa Jenneng Dibi" yang artinya ingatlah selalu pesan nenek moyang agar selalu hati-hati atau teliti serta tidak mudah terpengaruh orang lain dan harus sanggup berdiri di atas kekuatan diri sendiri dalam mengatur pemerintahan yang dapat menciptakan kesejahteraan, kemakmuran dan keadilan bagi masyarakat Madura umumnya dan daerah Pamekasan pada khususnya. ${ }^{13}$ Sesuai dengan firman Allah SWT yang berbunyi :

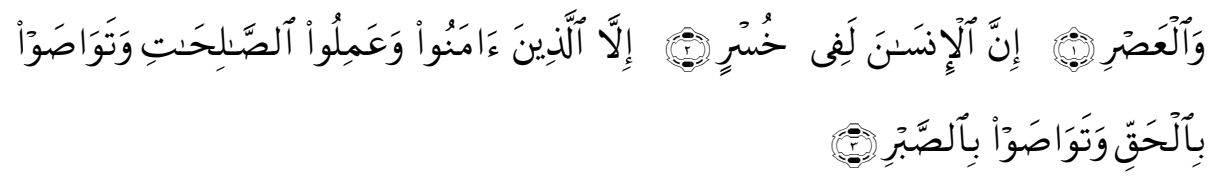

"Demi masa, sesungguhnya manusia itu benar-benar berada dalam kerugian, kecuali orang-orang yang beriman dan mengerjakan amal shaleh, dan nasehat menasihati supaya mentaati kebenaran, serta nasehat menasihati supaya menetapi kesabaran" (QS Al-Așr: 1- 3). ${ }^{14}$

Senada dengan ayat di atas Allah SWT menjelaskan dengan tegas dalam kitab sucinya Al-Qur'an yang berbunyi:

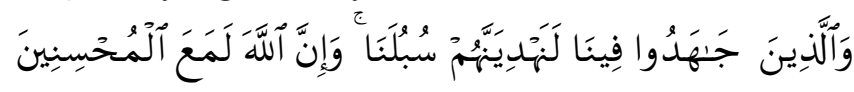

"Dan orang-orang yang berjihad untuk mencari keridhaan kami, benar-benar akan kami tunjukkan kepada mereka jalan-jalan kami. Dan sesungguhnya Allah benar-benar beserta orang-orang yang berbuat baik" (QS. Al-Ankabüt: 69). ${ }^{15}$

Internasional. Lihat: Huub de Jonge, "Madura dalam Empat Jaman: Pedagang, Perkembangan Ekonomi dan Islam”, (Jakarta: Gramedia, 1998). hlm 333.

${ }^{13}$ Tim Lembaga Pengkajian dan Penerapan Syari'at Islam (LP2SI) Kabupaten Pamekasan, Buku Saku Gerbang Salam: Mengenal Gerbang Salam. Ibid. hlm 9.

${ }^{14}$ Nandang Burhanudin, Al-Qur'an Wanita Ummahatul Muslimin, (Bandung: Media Fitrah Rabbani, 2011). hlm. 601.

${ }^{15}$ Ibid. hlm. 404. 
Perspektif sosiologis konsep kebijakan Gerakan pembangunan masyarakat islami (gerbangsalam) Di kabupaten pamekasan

Guna mewujudkan tujuan tersebut, dirumuskan tiga misi pokok dari Gerakan Pembangunan Masyarakat Islami (Gerbang Salam) di Kabupaten Pamekasan dengan berpijak kepada filosofi panutan masyarakat Madura, yakni bhuppa'-bhabhu'-ghuru-rato, yang dalam bahasa Indonesia berarti bapak, ibu, guru (kiai/ulama), dan ratu (Pemerintah). Jika dicermati, konsep bhuppa'-bhabhu'-ghuru rato ini mengandung pengertian adanya hierarkhi figur yang harus dihormati dan dipatuhi, mulai dari bapak, ibu, guru, dan terakhir ratu. ${ }^{16}$

Guna untuk mewujudkannya misi tersebut harus dilakukan langkahlangkah taktis. Pertama, Melakukan upaya dan langkah untuk membangun keluarga yang harmonis (sakinah) sebagai landasan terwujudnya tatanan masyarakat Islami. ${ }^{17}$ Kedua, Melakukan upaya dan langkah untuk membangun nuansa dan lingkungan pendidikan yang Islami sebagai landasan bagi terwujudnya generasi yang Islami. ${ }^{18}$ dan Ketiga, Melakukan upaya dan langkah untuk membangun aparatur pemerintah yang Islami, sebagai landasan bagi terwujudnya kesejahteraan dan ketentraman masyarakat yang diridhai Allah SWT. ${ }^{19}$

\footnotetext{
${ }^{16}$ Moh. Hefni, “Bhuppa'-Bhabhu'-Ghuru-Rato: Studi Konstruktivisme-Strukturalis tentang Hierarkhi Kepatuhan dalam Budaya Masyarakat Madura”, Jurnal KARSA Vol. No. (April, 2007).

${ }^{17}$ Konsep ini sebenarnya berpedoman pada firman Allah SWT dalam Al-Qur'an yang berbunyi:

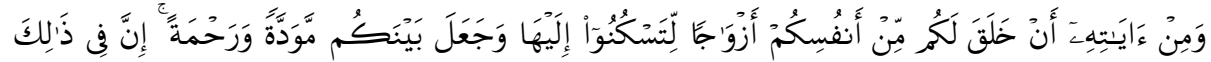

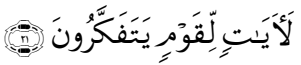

Artinya: Dan di antara tanda-tanda kekuasaan-Nya ialah Dia menciptakan untukmu isteriisteri dari jenismu sendiri, supaya kamu cenderung dan merasa tenteram kepadanya, dan dijadikan-Nya diantaramu rasa kasih dan sayang. Sesungguhnya pada yang demikian itu benar-benar terdapat tanda-tanda bagi kaum yang berfikir (Q.S. Ar Rum: 21). Lihat: Mahmud Junus, Terjemah Al-Qur'an Al-Karim, (Bandung, Al-Ma'arif, 1987). hlm. 365.

${ }^{18}$ Konsep ini didasarkan pada firman Allah SWT dalam Al-Qur'an yang berbunyi:

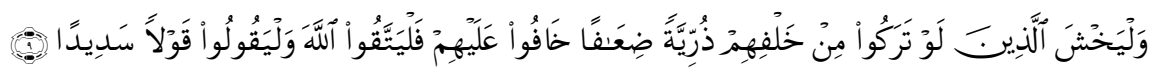

Artinya: Dan hendaklah takut kepada Allah orang-orang yang seandainya meninggalkan dibelakang mereka anak-anak yang lemah, yang mereka khawatir terhadap (kesejahteraan) mereka. oleh sebab itu hendaklah mereka bertakwa kepada Allah dan hendaklah mereka mengucapkan Perkataan yang benar (QS. Al-Nisā': 9). Lihat: Mahmud Junus, Terjemah AlQur'an Al-Karim, Ibid. hlm 70.

${ }^{19}$ Konsep ini didasarkan pada firman Allah SWT dalam Al-Qur'an yang berbunyi: 
Perspektif sosiologis konsep kebijakan

Gerakan pembangunan masyarakat islami (gerbangsalam)

Di kabupaten pamekasan

Gerakan Pembangunan masyarakat Islami (Gerbangsalam) ini meliputi tiga bidang garapan, yaitu bidang Aqidah, Syariat dan Akhlaq. Dari ketiga aspek tersebut diharapkan dapat menghasilkan pribadi muslim yang kāmil dan shämil, ${ }^{20}$ yang dalam hal ini memuat beberapa misi yaitu: Pertama, Membangun keluarga sakinah; Kedua, Membangun nuansa pendidikan yang Islami; dan Ketiga, Membangun aparatur pemerintah yang Islami.

Ketiga misi tersebut sehingga terwujud tatanan masyarakat yang Islami serta kesejahteraan dan ketentraman masyarakat. Di antara strategi yang digunakan adalah membangun movifasi kondusif bagi terciptanya perilaku dan sikap yang Islami serta membentuk kelompok pelopor sebagai penggerak pelaksanaan kebijakan Gerakan pembangunan masyarakat Islami (Gerbangsalam) di Kabupaten Pamekasan. ${ }^{21}$ Selain program umum yang meliputi Aqidah, Syari'ah dan Akhlaq, terdapat beberapa program pokok dalam kebijakan dan konsep Gerakan Pembangunan masyarakat Islami (Gerbang Salam) di Kabupaten Pamekasan yaitu: ${ }^{22}$ Pertama, Pendidikan, yaitu dengan membuat kebijakan yang mengarah pada pembangunan sistem pendidikan yang Islami; Kedua, Sosial Budaya, yaitu dengan membuat kebijakan yang mengarah pada kerangka Amar makruf nahi mungkar, seperti menutup aurat, dan shalat berjamaah; Ketiga, Kesehatan dan keluarga, yaitu dengan mengusahakan kebijakan yang mengarah pada pembangunan kesehatan dan keluarga yang sesuai dengan prinsip-prinsip Syariat Islam.

Konsep kebijakan Gerakan pembangunan masyarakat Islami (Gerbang Salam) baik dari proses formulasi dan implementasinya serta konsep-konsep yang tertuang dalam isi kebijakan sejatinya tidak bisa dipisahkan dari beberapa potensi yang dimungkinkan mendukung atas pelaksanaan serta keberhasilan implementasi kebijakan Gerakan pembangunan masyarakat Islami (Gerbangsalam) di Kabupaten Pamekasan, yaitu: Pertama, Populasi penduduk atau masyarakat terbesar di Kabupaten Pamekasan beragama

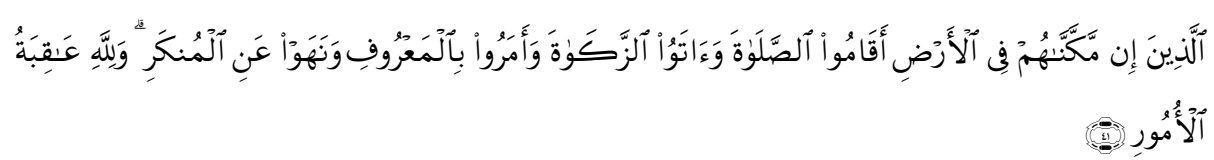

Artinya: Orang-orang yang jika Kami teguhkan kedudukan mereka di muka bumi niscaya mereka mendirikan sembahyang, menunaikan zakat, menyuruh berbuat ma'ruf dan mencegah dari perbuatan yang mungkar; dan kepada Allah-lah kembali segala urusan (QS. Al-Haj: 41). Lihat: Mahmud Yunus, Terjemah Al-Qur'an Al-Karim, Ibid. hlm 299.

${ }^{20}$ Tim Lembaga Pengkajian dan Penerapan Syari'at Islam (LP2SI) Kabupaten Pamekasan, Buku Saku Gerbang Salam: Mengenal Gerbang Salam. Ibid. hlm 3.

${ }^{21}$ Ibid. hlm 11.

${ }^{22}$ Ibid. hlm 48. 
Perspektif sosiologis konsep kebijakan

Gerakan pembangunan masyarakat islami (gerbangsalam)

Di kabupaten pamekasan

Islam. ${ }^{23}$ Kedua, adanya lembaga pendidikan yang tercatat tidak kurang dari 755 lembaga pendidikan yang didominasi oleh lembaga pendidikan yang berbasis Islam. Selain itu, juga ditunjang dengan tersedianya taman pendidikan Al-Qur'an. Ketiga, banyaknya sarana kegamaan, di mana dalam prakteknya juga dijadikan tempat untuk mengaji, mengkaji, dan atau tempat proses belajar mengajar Al-Qur'an, tercatat sebanyak 956 sarana keagamaan yang ditandai dengan banyaknya masjid, mushala, serta langgar/surau. Keempat, keberadaan perguruan tinggi di Kabupaten Pamekasan. Tercatat sebelum atau sejak tahun 2000 ada 6 perguruan tinggi, dan pada tahun-tahun berikutnya juga berdiri 4 perguruan tinggi lagi di wilayah Kabupaten Pamekasan. Kelima, Keberadaan Organisasi kemasyarakatan atau Ormas Islam di Pamekasan, seperti, Muhammadiyah; Nahdlatul Ulama'; Sarikat Islam; Persatuan Islam; Al Irsyad Al Islamiyah. Dan juga organisasi Islam lainnya yang juga ikut mewarnai dalam upaya meng-Implementasikan kebijakan Gerakan pembangunan masyarakat Islami (Gerbang Salam) di Kabupaten Pamekasan, seperti diantaranya: Hidayatullah; Hizbut Tahrir Indonesia (HTI); Front Pembela Islam (FPI); dan bahkan lembaga mitra pemerintah seperti Majelis Ulama' Indonesia (MUI) yang dalam perkembangan selanjutnya menjadi fasilitator berdirinya Forum komunikasi Ormas Islam (FOKUS) di Kabupaten Pamekasan. ${ }^{24}$ Keenam, keberadaan pondok pesantren (Ponpes) ${ }^{25}$ yang berjumlah 171 (seratus tujuh puluh satu) pondok pesantren yang tersebar di 13 (tiga belas) Kecamatan di wilayah

${ }^{23}$ Data penduduk Kabupaten Pamekasan berjumlah kurang lebih 688.380 jiwa yang terdiri dari laki-laki sebanyak 51,22\% dan perempuan sebanyak 48,78\%, yang tersebar di 13 Kecamatan, dan 189 Desa. Berdasarkan agama yang dianut masyarakat Kabupaten Pamekasan, sebanyak $92 \%$ dari total penduduk Kabupaten Pamekasan adalah beragama Islam. Lihat: Tim Lembaga Pengkajian dan Penerapan Syari'at Islam (LP2SI) Kabupaten Pamekasan, Gerbang Salam: Upaya mewujudkan masyarakat pamekasan amanah (aman dan sakinah) dalam rangka penegakan syari'at Islam melalui peningkatan pengamalan nilai-nilai syari'at Islam, disusun oleh LP2SI Kabupaten Pamekasan, Tidak diterbitkan, 2002. hlm 6.

${ }^{24}$ Forum komunikasi Ormas Islam (Fokus) Kabupaten Pamekasan sejatinya lahir dengan adanya kebijakan Gerakan pembangunan masyarakat Islami (Gerbang Salam) di Kabupaten Pamekasan. Forum komunikasi Ormas Islam (Fokus) Kabupaten Pamekasan beranggotakan organisasi kemasyarakatan yang berbasis Islam, seperti diantaranya: Muhammadiyah, Nahdlatul Ulama', Sarikat Islam, Persatuan Islam, Al Irsyad Al Islamiyah, dan Hidayatullah.

25 Dari 171 Pondok pesantren (PONPES), Pondok pesantren yang relatif besar serta mempunyai pengaruh yang sangat besar terhadap kehidupan sosial kemasyarakatan utamanya dalam dinamika politik lokal (local state) adalah Pondok pesntren Darul Ulum Banyuanyar; Pondok pesntren Mambaul Ulum Bata-bata; dan Pondok pesntren Miftahul Ulum Panyepen. Ketiga pondok pesantren besar dan berpengaruh ini berada di satu kecamatan yaitu Kecamatan Palengaan Kabupaten Pamekasan. Lihat: Muhammad Kosim, Pondok Pesantren di Pamekasan: Pertumbuhan dan Perkembangan, (Pamekasan: P3M STAIN Pamekasan, 2002). hlm 37-42. 
Perspektif sosiologis konsep kebijakan Gerakan pembangunan masyarakat islami (gerbangsalam) Di kabupaten pamekasan

Kabupaten Pamekasan. ${ }^{26}$ Ketujuh, keberadaan juru dakwah yang juga menjadi indikator penting terhadap keberhasilan implementasi kebijakan konsep Gerakan pembangunan masyarakat Islami (Gerbangsalam) sebagai model dan strategi dakwah di Kabupaten Pamekasan. ${ }^{27}$

Dalam tataran implementatif Gerakan pembangunan masyarakat Islami (Gerbangsalam) terdapat dua pendekatan, yaitu pendekatan formal dan pendekatan kultural. ${ }^{28}$ Pertama, Pendekatan formal dimana aktualisasinya terletak pada Policy Making (pembuat kebijakan) yang sejatinya mengacu pada program pokok dari kebijakan Gerakan pembangunan masyarakat Islami (Gerbang Salam) di Kabupaten Pamekasan; Kedua, pendekatan kultural lebih kepada pembiasaan aktifitas individu, masyarakat, keluarga, lembaga pemerintah dan lain sebagainya. Dimana setiap umat beragama dijamin oleh negara untuk melaksanakan ajaran agamanya secara benar, aman dan damai, Kewajiban negara dan pemerintah mendorong dan memfasilitasi umat Islam dalam menjalankan perintah agamanya karena hal itu merupakan hak dasar masyarakat secara konstitusional yang harus diberikan oleh pemerintah atas nama Negara.

Secara teoritis maupun praktis formalisasi penerapan syariat Islam membutuhkan institusi Negara atau kekuasaan politik, sehingga beberapa pemikir politik Islam beranggapan bahwa mendirikan sebuah lembaga Negara adalah kewajiban bersama (fardu kifáyah) ${ }^{29}$ yang sejalan dengan tuntutan syariat (maqāsid shari'ah). Al-Shātibī mengungkapkan bahwa tujuan syariat Islam adalah mengatur tatanan kehidupan manusia untuk

${ }^{26}$ Secara administratif, Ke 13 kecamatan yang dimaksud adalah : (1) Kecamat an Pamekasan; (2) Kecamatan Tlanakan; (3) Kecamatan Pademawu; (4) Kecamatan Galis; (5) Kecamatan Larangan; (6) Kecamatan Proppo; (7) Kecamatan Palengaan; (8) Kecamatan Pegantenan; (9) Kecamatan Kadur; (10) Kecamatan Pakong; (11) Kecamatan Waru; (12) Kecamatan Batu Marmar; dan (13) Kecamatan Pasean.

27 Tercatat sekitar 1.030 orang juru dakwah yang dengan keteladanan dan kearifan mereka dalam hlm kegamaan misi untuk mentransformasikan nilai-nilai Islami dalam kehidupan sehari-hari dapat diwujudkan di Kabupaten Pamekasan. Lihat: LP2SI, "Gerbang Salam: Upaya Mewujudkan Masyarakat Pamekasan Amanah (aman dan sakinah) dalam Rangka Penegakan Syari'at Islam melalui peningkatan pengamalan nilai-nilai syari'at Islam", Ibid. hlm 6.

28 Suli Faris, "Perda Syariat Islam Tak Menentang Pancasila" Lihat : Erie Hariyanto, GERBANG SALAM: Telaah atas pelaksanaannya di Kabupaten Pamekasan, Jurnal KARSA Vol. XV No. 1 (April 2009). hlm 80.

29 Pemikir politik muslim yang dengan tegas berpendapat tentang mendirikan sebuah pemerintahan dalam bentuk kekuasaan politik adalah al-Mawardi (974-1058) pemikiran intelektualnya dalam politik terlihat dalam kitab klasik al-Ahkām al-Sultaniyah, hlm. 5; Imam al-Ghazāli hlm. 1059-1111; dapat dilacak dalam karyanya al-Iqtiṣād fí al-I'tiqād, hlm. 215 . 
Perspektif sosiologis konsep kebijakan

mewujudkan kemaslahatan dan kebahagiaan manusia. ${ }^{30}$ Segala sesuatu yang datang dari Tuhan berupa perintah tentunya mengandung nilai kemaslahatan dan mendatangkan kebaikan, sebagaimana firman Allah dalam al-Qur'an:

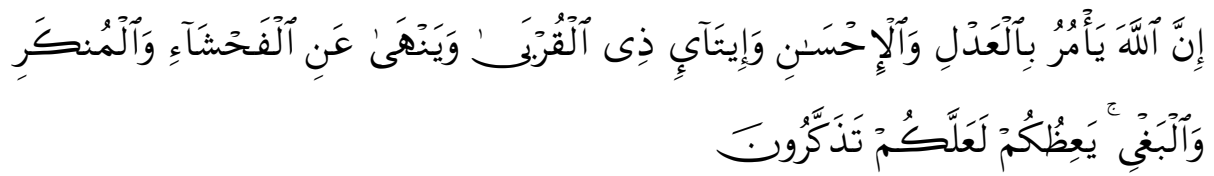

"Sesungguhnya Allah telah memerintahkan kamu berbuat adil dan berbuat kebajikan, serta menyantuni kerabat dekat, melarang tindakan keji dan mungkar serta permusuhan. Demikianlah Allah memberi pelajaran bagi kamu, agar kamu sadar" (QS. al-Nahl: 90). ${ }^{31}$

Selain itu, dalam surah dan ayat yang berbeda Allah SWT berfirman :

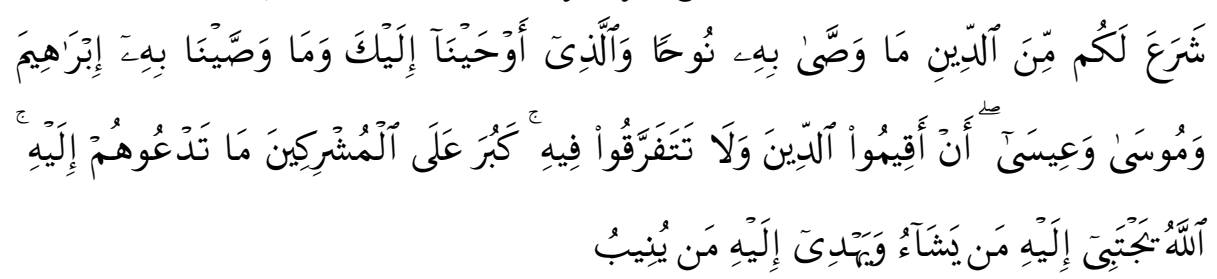

"Dia telah mensyariatkan bagi kamu tentang agama apa yang telah diwasiatkan-Nya kepada Nuh dan apa yang telah Kami wahyukan kepadamu dan apa yang telah Kami wasiatkan kepada Ibrahim, Musa dan Isa Yaitu: Tegakkanlah agama dan janganlah kamu berpecah belah tentangnya. Amat berat bagi orang-orang musyrik agama yang kamu seru mereka kepadanya. Allah menarik kepada agama itu orang yang dikehendaki-Nya dan memberi petunjuk kepada agama-Nya orang yang kembali kepada-Nya”. (QS. AlShūrā: 13$)^{32}$

Istilah "Syariat" yang sudah baku dalam bahasa Indonesia diartikan dengan hukum agama, atau yang bertalian dengan agama Islam. ${ }^{33}$ Secara etimologi berasal dari kata shara'a (bahasa Arab) dengan pengertian yang ditetapkan atau didekritkan. ${ }^{34}$ Dalam arti lain syariat adalah jalan atau cara

\footnotetext{
${ }^{30}$ Ahmad al-Mursì Husain Jauhar, Maqashid al-Syariyat fi al-Islam, terjemah Khikmawati (Jakarta: Amzah, 2010). hlm. xv; Al-Shāțibi, al-Muwafaqāt fî Uṣūl al-Ahkām, Juz II (ttp: Dār al-Fikr li al-tibā'ah wa al-Nashr). hlm.15-18.

${ }^{31}$ Zaini Dahlan, Al Qur'an dan Terjemahan Artinya, (Yogyakarta : UII Pres, 2009). hlm. 488.

${ }^{32}$ Ibid. hlm. 867-868.

${ }^{33}$ Depdikbud, Kamus Besar Bahasa Indonesia, (Jakarta : Balai Pustaka, 1991). hlm. 984.

${ }^{34}$ Taufik Adnan Amal dan Samsu Rizal Panggabean, Politik Syariat Islam dari Indonesia hingga Nigeria"(Jakarta: Pustaka Alvabet). hlm. 2.
} 
Perspektif sosiologis konsep kebijakan

Gerakan pembangunan masyarakat islami (gerbangsalam)

Di kabupaten pamekasan

menuju Allah melalui jalur ibadah, muamalah dan etika. ${ }^{35}$ Dalam keseharian syariat sering dipahami sebagai ketentuan atau hukum yang berasal dari Tuhan sehingga perlu diaktualisasikan dalam kehidupan. Syariat selalu dipahami sebagai fikih yakni pemahaman atau ilmu tentang hukum Islam. Syariat dan fiqih merupakan dua hal yang berbeda, tetapi memiliki kesamaan dan saling berkaitan, ${ }^{36}$ yaitu fokus kepada persoalan ibadah dan mu'amalah. Ibadah mengatur hubungan manusia dengan Tuhan-Nya seperti ketentuan shalat, puasa, zakat, haji, zikir dan sebagainya. Sedangkan mu'amalah mengatur hubungan manusia dengan sesama manusia dan alam lingkungannya. Oleh karena itu, tujuan syariat Islam adalah melindungi agama (hifz al-din), melindungi jiwa (hifz al-nafs), melindungi akal (hifz al'aql), melindungi kehormatan (hifz al-'irdh), melindungi harta (hifz al-māl) ${ }^{37}$ dan keseimbangan lingkungannya. ${ }^{38}$ Dengan demikian Islam dalam perspektif syari'at adalah kaffah, karena Syariat Islam yang kaffah menyentuh semua aspek pemenuhan hajat kehidupan manusia di dunia dengan berpegang teguh kepada nilai-nilai ilahiyah yang bersumber dari alQur'an dan Sunnah Rasulullah dalam segala aspek utamnaya dalam sistem berbangsa dan bernegara. ${ }^{39}$

Dari beberapa pandangan tentang urgensitas memasukkan nilai-nilai syari'at Islam dalam sistem pemerintahan atau dengan kata lain perlunya memformalisasikan syari'at Islam dalam bentuk kebijakan-kebijakan dalam sistem pemerintahan, formalisasi syari'at Islam secara teoritis baik pada tingkat Nasional (nasional state) maupun tingkat lokal (local state) setidaknya dihadapkan dengan tiga paradigma penting yaitu:

Pertama, Paradigma integratif (unified paradigm), yaitu agama dan Negara menyatu. Wilayah agama meliputi wilayah politik atau negara. Negara merupakan lembaga politik dan keagamaan sekaligus. Menurut

\footnotetext{
${ }^{35}$ Muhammad Saìd al-Asmawī, al-Syarì'ah al-Islāmiyah wa al-Qānūn al-Miṣrī, terj. Saiful Ibad, (Ciputat :Gaung Persada Press,2005). hlm. 11.

${ }^{36}$ Muhammad Said al-Asmawi menyebutkan bahwa, Syariat adalah produk hukum yang langsung pada Nash al-Qur'an dan Sunnah Rasulullah yang pasti (qat' $\left.{ }^{`} \bar{i}\right)$, sedangkan fiqih telah mengalami kodefikasi atau terlibatnya pemikiran ahli ijtihad yang disesuaikan dengan situasi dan kondisi setempat, sehingga disinilah muncul Qiyās, Ijmā', Urf dan sebagainya sebagai sumber pengembangan hukum Islam, namun akhir-akhir ini kata syariat Islam diidentikkan dengan Fiqih Islam atau hukum Islam. Ibid. hlm. 35.

${ }^{37}$ Ahmad al-Mursī Husain Jauhar, Maqashid al-Syar'iyah fi al-Islam, hlm. xiii.

38 Muhammad Ali, Kedudukan dan Pelaksanaan Hukum Islam dalam Negara Republik Indonesia dalam Hukum Islam Dalam Tatanan Masyarakat Indonesia, editor Cik Hasan Bisri, (Jakarta : Logos, 1998). hlm. 43.

39 Alyasa Abubakar, Bunga Rampai Pelaksanaan Syariat Islam (Pendukung Qanun Pelaksanaan Syariat Islam), (Banda Aceh: Dinas Syariat Islam Aceh, 2009). hlm. 43.
} 
Perspektif sosiologis konsep kebijakan

Gerakan pembangunan masyarakat islami (gerbangsalam)

Di kabupaten pamekasan

paradigma ini, kepala negara adalah pemegang kekuasaan agama dan kekuasaan politik. Pemerintahan diselenggarakan atas dasar kedaulatan Tuhan (divine sovereignty). Pendukung paradigma ini meyakini bahwa kedaulan berasal dan berada di tangan Tuhan. Dengan demikian, dalam perspektif paradigma integratif pemberlakuan dan penerapan syariat Islam sebagai hukum positif Negara adalah hal yang niscaya. ${ }^{40}$

Kedua, Paradigma simbiotik (symbiotic paradigm), yaitu agama dan negara berhubungan secara simbiotik, yakni suatu hubungan yang bersifat timbal balik dan saling memerlukan. Dalam hal ini, agama memerlukan negara dan dengan negara agama dapat berkembang. Sebaliknya, negara memerlukan agama dan dengan agama negara dapat berkembang dalam bimbingan etika dan moral-spiritual. ${ }^{41}$ Paradigma ini terkadang disebut pola hubungan yang tidak formal atau tidak resmi antara agama dan negara. Dalam sistem kenegaraan dan pola pemerintahan seperti ini, agama secara resmi tidak dijadikan dasar negara dalam konstitusinya, tetapi pola hubungan antara keduanya dibuat berlangsung secara tidak formal. ${ }^{42}$

Ketiga, Paradigma sekular (secularistic paradigm) adalah paradigma yang menolak kedua paradigma di atas, yaitu paradigma integratif dan paradigma simbiotik. Sebagai gantinya paradigm sekular mengajukan pemisahan (disparatis) agama atas Negara dan pemisahan negara atas agama. Konsep al-dunyā al-akhïrah al-dīn al-dawlah atau umür al-dunyā umür al-din di-dikotomikan secara diametral. Dalam konteks Islam, paradigma ini menolak pendasaran negara kepada Islam, atau paling tidak, menolak determinasi Islam pada bentuk tertentu dari Negara. ${ }^{43}$ Menurut paradigma ini, syariat Islam tidak dapat begitu saja diterapkan dan diberlakukan dalam satu wilayah politik tertentu. Di samping itu, syariat Islam tidak dapat dijadikan hukum positif kecuali telah diterima sebagai hukum Nasional.

Realitas di atas secara sosiologis menunjukkan bahwa terjadi proses interaksi yang saling mempengaruhi antara struktur pemerintah dengan seperangkat kebijakannya, dengan struktur agama dalam kehidupan masyarakat, dimana masing-masing struktur yang ada dalam masyarakat

\footnotetext{
${ }^{40}$ M. Dien Syamsuddin, Usaha Pencarian Konsep Negara dalam Sejarah Pemikiran Politik Islam, dalam Ulumul al-Qur'an: Jurnal Ilmu dan Kebudayaan, No. 2, Vol. 4 (Jakarta: LSAF dan ICMI, 1993). hlm. 4.

${ }^{41}$ Ibid. hlm. 6.

${ }^{42}$ Faisal Ismail, Pijar-pijar Islam: Pergumulan Kultur dan Struktur, (Yogyakarta: LESFI, 2002). hlm. 74.

${ }^{43}$ M. Dien Syamsuddin, Usaha Pencarian Konsep Negara dalam Sejarah Pemikiran Politik Islam, dalam Ulumul al-Qur'an. Ibid. hlm. 7
} 
Perspektif sosiologis konsep kebijakan Gerakan pembangunan masyarakat islami (gerbangsalam) Di kabupaten pamekasan

bersifat fungsional dan saling mempengaruhi, dimana dalam kajian sosiologi dikenal dengan teori funsionalisme strukturalime yang merupakan buah fikir Emile Dhurkheim. Fungsionalisme Strukturalisme memusatkan perhatian pada fungsi satu struktur sosial atau pada fungsi satu institusi sosial tertentu saja. Teori ini berpandangan bahwa, masyarakat merupakan suatu sistem sosial yang terdiri atas bagian-bagian atau elemen-elemen yang saling berkaitan dan saling menyatu dalam keseimbangan. Perubahan yang terjadi pada suatu bagian akan membawa perubahan terhadap yang lain. Asumsi dasarnya adalah bahwa setiap struktur dalam sistem sosial, fungsional terhadap aspek yang lain. Sebaliknya kalau tidak fungsional maka struktur itu tidak akan ada atau akan hilang dengan sendirinya. Penganut teori ini cenderung untuk melihat hanya kepada sumbangan satu sistem atau peristiwa terhadap sistem yang lain dan karena itu mengabaikan kemungkinan bahwa suatu peristiwa atau sistem dapat beroperasi menentang sistem-sistem yang lainnya dalam suatu sistem sosial. ${ }^{44}$ Penganut teori ini beranggapan bahwa semua peristiwa dan semua struktur adalah fungsional bagi suatu masyarakat. Perubahan dapat terjadi perlahanlahan dalam masyarakat. Kalau terjadi konflik penganut teori fungsionalisme Struktural memusatkan perhatiannya pada masalah bagaimana cara menyelesaikannya, sehingga masyarakat tetap dalam keadaan keseimbangan. ${ }^{45}$

Pada perkembangan selanjutnya, teori fungsionalisme struktur dikembangkan oleh Talcott Parson. Pembahasan teori fungsionalisme struktural Parson diawali dengan empat skema penting mengenai fungsi untuk semua sistem tindakan, skema tersebut dikenal dengan sebutan skema AGIL. ${ }^{46}$ Menurut parson ada empat fungsi penting yang mutlak dibutuhkan bagi semua sistem sosial dalam masyarakat untuk menjalankan fungsinya yaitu, adaptasi (A); pencapaian tujuan atau goal attainment (G), integrasi (I), dan Latensi (L). Keempat fungsi tersebut wajib dimiliki oleh semua sistem agar tetap bertahan (survive).

Adaptation (A), fungsi yang amat penting di sini sistem harus dapat beradaptasi dengan cara menanggulangi situasi eksternal yang gawat, dan sistem harus bisa menyesuaikan diri dengan lingkungan juga dapat menyesuaikan lingkungan untuk kebutuhannnya.

${ }^{44}$ George Ritzer, Teori sosiologi: Dari sosiologi klasik sampai perkembangan terakhir postmodern, alih bahasa: Saut Pasaribu, Rh. Widada, Eka Adi Nugraha, (Yogyakarta: Pustaka belajar, 2003), hlm. 21.

45 Ibid. hlm. 22.

${ }^{46}$ Moh. Fadil dan Trio Supriyanto, Sosiologi Pendidikan, (Malang: UIN-Maliki Press, 2010), hlm. 64 . 
Perspektif sosiologis konsep kebijakan

Gerakan pembangunan masyarakat islami (gerbangsalam)

Di kabupaten pamekasan

Goal attainment (G), pencapainan tujuan sangat penting, dimana sistem harus bisa mendefinisikan dan mencapai tujuan utamanya.

Integration (I), sebuah sistem harus mampu mengatur dan menjaga antar-hubungan bagian-bagian yang menjadi komponennya, selain itu mengatur dan mengelola ketiga fungsi yang ada, yaitu Adaptation (A), Goal attainment $(\mathrm{G})$, dan Latency $(\mathrm{L})$.

Latency (L), sistem harus mampu berfungsi sebagai pemelihara pola, sebuah sistem harus memelihara dan memperbaiki motivasi pola-pola individu dan kultural.

Jikalau keempat teori sistem di atas dihadapkan dengan realitas kebijkan Gerakan pembangunan masyarakat Islami (Gerbangsalam) di Kabupaten Pamekasan, dapat dijelaskan bahwa Pertama, adaptasi (adaptation $=A$ ) dilaksanakan oleh organisme prilaku dengan cara melaksanakan fungsi adaptasi, yakni menyesuaikan diri dan mengubah lingkungan eksternal. Kedua, fungsi pencapaian tujuan (Goal attainment= $G$ ) difungsikan oleh sistem kepribadian dengan menetapkan tujuan sistem dan memobilisasi sumber daya untuk mencapainya. Ketiga, Integrasi (integration = I) dilakukan oleh sistem sosial, dan Keempat, laten (latency= L) difungsikan sistem kultural dalam kehidupan sosial masyarakatnya. Bagaimana sistem kultural bekerja? Jawabannya adalah dengan menyediakan aktor (individu), seperangkat norma (aturan, kebijakan), dan nilai yang memotivasi aktor untuk bertindak.

\section{Epilog}

Konsep kebijakan Gerakan pembangunan masyarakat Islami (Gerbangsalam) merupakan rangkaian kebijakan dalam bentuk keputusan Bupati yang kelahiran dan kehadirannya adalah dampak dari reformasi total pada tahun 1998 dan bergulirnya spirit otonomi daerah (Otoda), yang sejatinya adalah amanat undang-undang yang berskala nasional, yang menghendaki perubahan paradigma pemerintahan dari sentralisasi birokrasi menuju pemerintahan desentralisasi demokrasi. Konsep kebijakan Gerakan pembangunan masyarakat Islami (Gerbangsalam) di Kabupaten Pamekasan, merupakan rangkaian kebijakan yang menginginkan nilai-nilai syari'at Islam sebagai dasar dalam perumusan dan implementasikan kebijakan serta model dan strategi dakwah Islamiyah di Kabupaten Pamekasan, yang secara fundamental terdiri dari empat garapan dan atau sasaran penting yaitu Pertama, membangun keluarga Islami; Kedua, membangun lingkungan pendidikan yang Islami; Ketiga, membangun aparatur pemerintahan yang Islami; dan Keempat, membangun sosial budaya yang Islami; yang secara sosiologis saling berinteraksi, dan saling mempengaruhi antara struktur 
Perspektif sosiologis konsep kebijakan

Gerakan pembangunan masyarakat islami (gerbangsalam)

Di kabupaten pamekasan

pemerintah dengan struktur-struktur lainnya pada masyarakat Kabupaten Pamekasan dalam sistem berbangsa dan bernegara, guna terwujudnya masyarakat Kabupaten Pamekasan yang aman, tenteram, sejahtera, yang dijiwai dengan nilai-nilai syari'at Islam yang diridhai Allah SWT.

\section{Daftar Pustaka}

Abubakar, Alyasa. Bunga Rampai Pelaksanaan Syariat Islam: Pendukung Qanun Pelaksanaan Syariat Islam. Banda Aceh: Dinas Syariat Islam Aceh, 2009.

Adnan Amal, Taufik, dan Rizal Panggabean, Samsu. Politik Syariat Islam dari Indonesia hingga Nigeria”. Jakarta: Pustaka Alvabet.

Ali, Muhammad. Kedudukan dan Pelaksanaan Hukum Islam dalam Negara Republik Indonesia dalam Hukum Islam Dalam Tatanan Masyarakat Indonesia. Jakarta: Logos, 1998.

Alim, Muhammad. Perda-Perda Bernuansa Islam dan Hubungannya Dengan Konstitusi. Jakarta: Mahkamah konstitusi Republik Indonesia, Jurnal Hukum, Vol 17 Januari 2010:119-142.

Al-Markassary, Ridwan. Matinya kebesan sipil di-tengah kuasa Perda Syari'ah Islam di Indonesia, http://www.csrc.or.id.

Al-Mawardi (974-1058) pemikiran intelektualnya dalam politik terlihat dalam kitab klasik al-Ahkam al-Sulthaniyah, dapat dilacak dalam karyanya al-Iqtișād fī al-I'tiqàd.

Al-Shātibìi, al-Muwafaqāt fî̀ Ușūl al-Ahkām, Juz II (ttp: Dār al-Fikr littibā'ah wa al-Nashr).

Dahlan, Zaini. Al Qur'an dan Terjemahan Artinya. Yogyakarta: UII Pres, 2009.

Depdikbud. Kamus Besar Bahasa Indonesia. Jakarta: Balai Pustaka, 1991.

Erie Hariyanto, GERBANG SALAM : Telaah atas pelaksanaannya di Kabupaten Pamekasan, Jurnal KARSA Vol. XV No. 1 (April 2009).

Fadil, Moh. dan Supriyanto, Trio. Sosiologi Pendidikan. Malang: UINMaliki Press, 2010.

Hefni, Moh. Bhuppa'-Bhabhu'-Ghuru-Rato: Studi KonstruktivismeStrukturalis tentang Hierarkhi Kepatuhan dalam Budaya Masyarakat Madura", Jurnal KARSA Vol. No. (April, 2007).

Husain Jauhar, Ahmad al-Mursì. Maqāsid al-Shariat fì al-Islamī, terjemah Khikmawati. Jakarta: Amzah, 2010.

Huub de Jonge. Madura dalam Empat Jaman: Pedagang, Perkembangan Ekonomi dan Islam. Jakarta: Gramedia, 1998. 
Perspektif sosiologis konsep kebijakan

Gerakan pembangunan masyarakat islami (gerbangsalam)

Di kabupaten pamekasan

Ismail, Faisal. Pijar-pijar Islam: Pergumulan Kultur dan Struktur. Yogyakarta: LESFI, 2002).

Junus, Mahmud. Terjemah Al-Qur'an Al-Karim. Bandung, Al-Ma'arif, 1987.

Kosim, Muhammad. Pondok Pesantren di Pamekasan: Pertumbuhan dan Perkembangan. Pamekasan: P3M STAIN Pamekasan, 2002.

Nandang Burhanudin. Al-Qur'an Wanita Ummahatul Muslimin. Bandung: Media Fitrah Rabbani, 2011.

Ritzer, George. Teori sosiologi: Dari sosiologi klasik sampai perkembangan terakhir postmodern, alih bahasa: Saut Pasaribu, Rh. Widada, Eka Adi Nugraha. Yogyakarta: Pustaka belajar, 2003.

Rumadi, Perda Syari'ah Islam: Jalan lain menuju Negara Islam? Tahwirul Afkar: Jurnal refleksi pemikiran keagamaan dan kebudayaan Islam; perda syari'at Islam menuai makna, Edisi No. 20 Tahun 2006.

Sirait, Sihombing. Manjemen. Jakarta: Bumi aksara, 1991.

Syafiie, Inu Kencana. Ilmu Administrasi Publik. Jakarta: Rineka Cipta, 2007.

Saìd al-Asmawi, Muhammad. al-Shari'ah al-Islāmiyah wa al-Qānūn alMișri, terjemah. Saiful Ibad. Ciputat: Gaung Persada Press,2005.

Syamsuddin, Dien M. Usaha Pencarian Konsep Negara dalam Sejarah Pemikiran Politik Islam, dalam Ulumul al-Qur'an: Jurnal Ilmu dan Kebudayaan, No. 2, Vol. 4. Jakarta: LSAF dan ICMI, 1993.

Tahir, Arifin. Analisis implementasi kebijakan empat pilar pengembangan Universitas Negeri Gorontalo. Gorontalo: Universitas Negeri Gorontalo, 2012.

Tim Lembaga Pengkajian dan Penerapan Syari'at Islam (LP2SI) Kabupaten Pamekasan, Gerbang Salam: Upaya mewujudkan masyarakat pamekasan amanah (aman dan sakinah) dalam rangka penegakan syari'at Islam melalui peningkatan pengamalan nilai-nilai syari'at Islam, disusun oleh LP2SI Kabupaten Pamekasan, Tidak diterbitkan, 2002.

Tim Lembaga Pengkajian dan Penerapan Syari'at Islam (LP2 SI) Kabupaten Pamekasan. Buku Saku Gerbang Salam: Mengenal Gerbang Salam. Pamekasan: LP2SI Pamekasan, 2011.

Undang-undang Nomor 32 Tahun 2004 tentang Pemerintahan Daerah.

Widodo, Joko. Analisis Kebijakan Public. Malang: Bayumedia Publishing, 2007.

Yunus, Mahmud. Terjemah Al-Qur'an Al Karim. Bandung: Alma'arif, 1967. 